\title{
The Use of Third Party Website Providers by Australian Small Businesses
}

\author{
Stephen Burgess \\ Victoria University, Australia
}

\begin{abstract}
It has been known for some time that small businesses have had access to third party websites to extend their web presence. However, little is known about the extent to which they use them and how the usage may differ across various types of small businesses. This paper addresses this by examining the third party website use of 50 Australian small businesses that have used the services of 139 third party websites. There are differences that can be attributed to different business categories. The majority of third party websites used were directory services, with more complex portal websites being used by the accommodation, café and restaurant; retail and personal services business categories. Accommodation, café and restaurant businesses were separate from other sectors as they had the most third party links, incorporated the most sophisticated third party services - but also the lowest representation in the most commonly used third party websites. This implied that was some consolidation still to come in the number of third party providers in that sector. Most businesses used directories that were free to use or were free for basic listings with a fee for extended listings. However, some $30 \%$ of the third party website usage did involve some fee.
\end{abstract}

Keywords: small business; web presence; third party websites; portals; study

\section{Introduction}

This paper examines the extent of the web presence for small businesses. The author has coined the term 'web presence' to encapsulate more than just the websites of small businesses - but also other online 'third party' services (be they portals, directories or otherwise) that they employ. Initially, this paper examines the notion of the web presence and the types of other online services that small businesses may employ. Then, through a classification of the web presence of 50 Australian small businesses, it provides the first detailed picture of how small businesses employ these extra services.

\section{Background}

Small businesses face many challenges when setting up their websites - they have limited resources (skills; finances and available time) and are often considered to be poor planners. When they do recognise a shortfall in expertise they often do not know where to source relevant skills. Small business owner/managers are known to be generally conservative in their use of information and communications technologies, including the Internet [4]. However, small businesses are increasingly turning to websites as a means of supporting their business activities. For instance, a recent study of small businesses in Australia [10] revealed that $60 \%$ of 1436 small and medium sized enterprises had a website and that $74 \%$ of them had felt that the website had increased their business effectiveness.

Each website consists of a combination of 'website features'. A 'website feature' can be something as simple as listing the business address and telephone number on the website, but it can also include more advanced features such as 'Frequently Asked Questions', weblogs (blogs) and online ordering and purchasing. Typically, different website features will be incorporated by businesses in different industries. In a recent Telstra study of Australian small and medium sized businesses [10], the most commonly identified features on small and medium sized business websites were:

- Contact details (99\% of respondents)

- Email address (95\%)

- Product descriptions (91\%)

- Company history/ information (88\%)

- Product images (74\%)

- Email enquiry form (69\%)

- Map to locate business (64\%)

- Details of management team (54\%)

- Prices (38\%)

- Company news (36\%)

- $\quad$ Special offers (35\%)

- Independent reviews (30\%)

Small businesses can often add or remove some of these features over a period of time as they have a website redesign or perhaps change their Internet service provider - but sometimes these changes can occur without any (apparent) logical reason. For 
instance, the feature may have been overlooked during a website update and not included in the newer version of the website. A study of small business websites over time has shown that this has happened with features as simple as the business telephone number. This means that a primary method for contacting the business is absent from the website [3].

There are many ways to classify website features such as those listed above. For instance, 'virtual' dimensions could be used by a business to help them select which Internet features to employ when engaging with customers [7]:

- Virtual information space - this includes online advertising and posting business information. It would include features such as contact details and company history as listed in the Telstra Corporation study [10].

- Virtual communication space - which is where the business engages in a two-way online communication with its customers, typically through email, chat facilities or bulletin boards. The Telstra Corporation study found that $97 \%$ of respondents had their email address listed on their website.

- Virtual distribution space - allows for the delivery of digital goods (such as online books, software) and services (such as financial advice).

- Virtual transaction space - allows for the acceptance of online orders and payments.

Burgess et al [4] suggest that website features typically fall into one of five categories:

- Features that help customers to locate and/or contact the business (such as the business address, telephone number and email details). [Information and Communication spaces]

- Features that tell a customer about the products and services of a business (for instance, online catalogues). [Information space]

- Features that help to provide added value for goods and services (such as instructions on how to use products effectively). [Information space]

- Features that assist in building an online community of customers (for instance, bulletin boards, blogs or 'wikis'). [Communication space]

- Features that allow customers to order, pay for and sometimes even receive goods online (for instance, music downloads). [Transaction and Distribution spaces].

Thus, different categories of website features may assist small businesses in different ways, by improving business efficiencies, adding value to products and services and generally assisting with the promotion of the business. Website features can thus be directly related to business benefits and matched to the overall business strategy and aims [4].

However, there are now many more options available to a small business when setting up their web presence. Many of these are associated with web portals and directories. A portal is a special website designed to act as a gateway to give access to other related sites [8] or provides services. A directory provides a link to details of the business or to its website. Typically, portals can operate in all of Jelassi and Enders' spaces, whereas directories operate in the information space (and sometimes the communication space via features such as email forms)

The idea of a portal is that it is a website that users will return to a number of times and is often seen as a starting point for specific groups of users when they access the web. Portals can facilitate access to other sites that may be closely related (in the case of special purpose portals) or quite diverse (in the case of general portals) - or for small businesses it may be that web users will discover details about the business through the portal (or directory). The potential benefits to small businesses is that there is access to website features that they may not previously have had access to because of their complexity or setup cost, or the chance to access expanded markets.

The core elements of portals are search, content, community building, commerce and personalproductivity applications [6]. Small businesses should consider whether portals can provide these services on a more cost effective or efficient basis than they could themselves or provide services beyond what they could normally expect to provide. Thus, some of the advantages that portals offer to small businesses are [9]:

- A secure environment and established infrastructure: portals can provide a secure online environment to small businesses. The capital outlay for setting up online ordering and purchases can be significant for a small business. The problems are reduced, however, by being part of a portal that provides these services.

- Search and directory services: search engines and directories that list the portals can enable the web users to find the gateway to small businesses on the web via these portals, saving substantially on costs. These are the functions typically provided by a directory website.

- Community building and regional relationships: community building features such as chat rooms and message boards may be included in the portal infrastructure. In addition, regional portals provide the advantage that participating small businesses can feel that they are contributing to the local community. There are also cost and efficiency benefits through dealing with 
businesses in the local area, especially where physical products are being transacted. Of course, social networking websites (providing features such as weblogs) are specifically set up to encourage these types of relationships.

To what extent have small businesses been employing the services of portals and directories? A study of some 200 Bed and Breakfast operators in Australia [1] asked the operators to rate the importance of having website features on their own website and on 'third party' sites. The ratings ranged from Not Important (' 1 ') to Very Important ('5'). These are represented in Table 1.

Note that Information space features were seen to be the most important on small business' own website and on third party websites. Supporting the notion that portals can provide complex website features for small businesses, the only feature where 'third party' websites were rated as more important (with a statistically provable difference) was the online payment feature [1].

Table 1. Bed and Breakfast Operator Views of Importance of Website Features (adapted from [1]: Table 1).

\begin{tabular}{|l|c|c|}
\hline Website Feature & $\begin{array}{c}\text { On own } \\
\text { website } \\
\text { (average } \\
\text { rating) }\end{array}$ & $\begin{array}{c}\text { On third } \\
\text { party } \\
\text { website } \\
\text { (average } \\
\text { rating) }\end{array}$ \\
\hline $\begin{array}{l}\text { Accommodation } \\
\text { pictures }\end{array}$ & 4.87 & 4.82 \\
\hline $\begin{array}{l}\text { Accommodation } \\
\text { description }\end{array}$ & 4.85 & 4.81 \\
\hline $\begin{array}{l}\text { Business contact details } \\
\text { (eg telephone; email) }\end{array}$ & 4.82 & 4.78 \\
\hline $\begin{array}{l}\text { Location information } \\
\text { (eg address) }\end{array}$ & 4.72 & 4.79 \\
\hline Location map & 4.59 & 4.68 \\
\hline $\begin{array}{l}\text { Accommodation } \\
\text { pricing }\end{array}$ & 4.48 & 4.62 \\
\hline $\begin{array}{l}\text { Business details } \\
\text { ("About us") }\end{array}$ & 4.20 & 4.14 \\
\hline Customer enquiry form & 3.75 & 4.09 \\
\hline $\begin{array}{l}\text { Information relating to } \\
\text { tourism }\end{array}$ & 3.73 & 4.27 \\
\hline Links to other websites & 3.00 & 3.44 \\
\hline Online payment feature & 2.69 & 3.40 \\
\hline $\begin{array}{l}\text { Information privacy } \\
\text { policy }\end{array}$ & 2.57 & 2.94 \\
\hline Accommodation videos & 2.00 & 2.23 \\
\hline $\begin{array}{l}\text { Online blog for } \\
\text { customers }\end{array}$ & 1.94 & 2.44 \\
\hline $\begin{array}{l}\text { Frequently Asked } \\
\text { Questions (FAQ) }\end{array}$ & 1.93 & 2.60 \\
\hline $\begin{array}{l}\text { Pod casts (audio } \\
\text { presentation) }\end{array}$ & 1.54 & 1.80 \\
\hline
\end{tabular}

Small businesses have had options other than their own websites in which to build their web presence for a number of years. For instance, it is not unusual for small accommodation businesses to be listed on the websites of 5-20 different online accommodation services! [1]. From the example above it appears that there may be attractions in using the online shopping cart features of a portal. A simpler example of an 'extended web' presence is when a small business provides its basic contact information to regional or industry portals. This can be quite inexpensive and, because the information does not change readily, is relatively easy to maintain [2].

In relation to payment models for third party website services, Burgess and Tatnall [5] proposed the 'Revenue-Content' model to provide a means of classification for how third party portals funded their activities. Included in this model were the types of services they could provide in regards to this revenue. This list included advertising services, which are excluded here as the focus of this paper is on the businesses that use third party services. The types of services provided to businesses by third party providers include the provision of information about the business, transactions facilities for the customers of the business (to make online orders and/or payments) and other services. Although excluded from this list, advertising revenue may be particularly important for those third party services that offer their online listings to business for no cost.

It is not really known to what extent small businesses are taking advantage of the extended web to build their web presence through using the services of third party websites such as portals and directories. Thus, this paper reports on a study that endeavours to determine how this may be occurring.

\section{The Study}

The study was conducted in early 2010 and involved examining the 'third party' websites of 50 Australian small businesses across ten different business categories (as used in the Telstra Corporation study [9] mentioned earlier in the paper). It can be difficult to identify small businesses as the definitions of 'small business' differ around the world [4]. In this instance, the author adopted the simple technique of using the search term "we are a small business" in the search engine Google (www.google.com.au) and selected only Australian websites. In addition, a specific business category (such as 'manufacturing') was added to the search term until five businesses were identified in each of the ten business categories. Care was taken to avoid businesses that had statements such as "we are a small business that has grown into a large business" on their websites. For each business, a research 
assistant followed this procedure:

1. The full name of the business was typed into into Google, surrounded by quotation marks ("business name").

2. The research assistant selected 'Pages from Australia' and then commenced the search.

3. In most cases the businesses' own website was the top ranked item, or at least was very close to the top ranking.

4. The research assistant ignored websites that contained:

- A review of the business offerings or articles about the business (typically online newspaper articles).

- Other businesses that had listed the business as a client, or had been sponsored by the business (although it could perhaps be argued that the latter is some type of 'extended' web presence if it is planned).

- Other organisations that had used the products or services of the business and had listed this on their website (for instance, 'catered by xxxxxxx').

- Temporary listings - such as one-off events the business was involved with.

- Anything else that does not involve the business using another online service on an ongoing basis.

5. What was left was typically a list of websites that the business had intentionally approached to be listed on their website and, in some cases, to use the online services they offered.

6. The research assistant then listed the details of UP TO 5 of these other services - but only go as far as three Google pages (or 30 listings). The idea behind this was that a typical user will certainly not go beyond this level to find a business (and would probably not even go this far).

7. Finally, if a particular third party site showed up more than once in the listings it was NOT counted twice.

\section{Results and Discussion}

The main results of the study are shown in Table 2. The first three columns represent the business category, the number of businesses that had third party website listings (maximum five for each category) and the total number of third party listings. For instance, in the accommodation, café and restaurant category all five businesses had third party websites, with a total of 21 listings across the five businesses. Note that some of the listings were used by more than one business and these were counted separately for each business.

Table 2 shows that were some quite notable differences between the leading categories and those that barely employed third party services. For instance, only two of the five community/health services businesses used third party services and only three of the communication, property and business services category used these services.

In all, $82 \%$ of the businesses used at least one third party service. Of these, the average usage was 3.4 third party services (remembering that each business was 'capped' at five services, so this average may have been marginally higher).

In relation to the particular website features, Table 2 divides these into information space, communication space and transactions space features. Not surprisingly (when considering the literature review), the most common features were the name of the business (listed on all of the third party websites) and the address and telephone number of the business (listed on around eight out of ten of the sites). An interesting finding is that the percentage of services that have the address and telephone number is lower for the accommodation, café and restaurant and retail categories. The lower proportion of addresses in the accommodation, café and restaurant category is quite strange as it would seem that certainly the address is something that web users would be interested in! This mainly occurred for two of the accommodation businesses. Interestingly, these listings also failed to provide a map showing the location of the business. In the case of the retail businesses, the lack of address and telephone details may be explained by the high proportion (94\%) of third party services that had a direct link to the business web site address (URL in Table 2) - where address and telephone information would more than likely be located.

There was some variation throughout the categories in relation to the provision of information 'about the business', with on average half of the services providing this information. Around half of the services in the accommodation, café and restaurant category had pictures ('images' in Table 2 ), whilst a number of categories had virtually no images as part of the third party services.

In relation to the communication space, the author was quite surprised to see the simplistic email form being used on nearly one third of the sites, with only one in seven sites listing the email address of the business.

One of the most interesting findings was in relation to the transactions space - where the author was again surprised that only the accommodation, café and restaurant category had any type of online booking and/or online sales - and this was really only evident in the accommodation subcategory. This supports the Bed and Breakfast finding mentioned earlier in the chapter. 
International Journal of Digital Society (IJDS), Volume 2, Issue 1, March 2011

Table 2. Small Business Third Party Website Features by Business Category

\begin{tabular}{|c|c|c|c|c|c|c|c|c|c|c|c|c|c|c|}
\hline \multirow[b]{3}{*}{ Business Category } & \multirow{3}{*}{$\begin{array}{l}\text { Number of } \\
\text { businesses with } \\
\text { third party } \\
\text { services } \\
\text { (Maximum: } 5 \text { ) }\end{array}$} & \multirow{3}{*}{$\begin{array}{c}\text { Overall } \\
\text { number of } \\
\text { services } \\
\text { identified } \\
\text { (Maximum: } \\
\text { 25) }\end{array}$} & \multicolumn{12}{|c|}{ Website Features ( $\%$ use) } \\
\hline & & & \multicolumn{8}{|c|}{ Information Space } & \multicolumn{3}{|c|}{ Communication Space } & \multirow{2}{*}{$\begin{array}{c}\begin{array}{c}\text { Transactions } \\
\text { Space }\end{array} \\
\begin{array}{c}\text { Bookings and/or } \\
\text { payments }\end{array}\end{array}$} \\
\hline & & & Name & Address & Tel & Fax & Map & URL & $\begin{array}{c}\begin{array}{c}\text { About } \\
\text { the } \\
\text { business }\end{array} \\
\end{array}$ & Images & Email & $\begin{array}{l}\text { Email } \\
\text { form }\end{array}$ & $\begin{array}{c}\text { User } \\
\text { Reviews }\end{array}$ & \\
\hline $\begin{array}{l}\text { Accommodation, Café, \& } \\
\text { Restaurant }\end{array}$ & 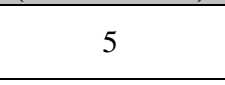 & 21 & 100 & 57 & 43 & 14 & 57 & 24 & 62 & 48 & 19 & 48 & 14 & 43 \\
\hline Retail & 5 & 16 & 100 & 44 & 56 & 0 & 31 & 94 & 81 & 13 & 13 & 25 & 6 & - \\
\hline Personal Services & 5 & 16 & 100 & 100 & 100 & 19 & 81 & 50 & 31 & 13 & 25 & 38 & 19 & - \\
\hline Manufacturing & 5 & 16 & 100 & 81 & 75 & 25 & 69 & 63 & 44 & 6 & 19 & 25 & 25 & - \\
\hline Building/ Construction & 4 & 16 & 100 & 100 & 94 & 38 & 50 & 38 & 44 & 6 & - & 19 & 19 & - \\
\hline Wholesale & 3 & 15 & 100 & 100 & 93 & 47 & 60 & 67 & 60 & 20 & 33 & 27 & 7 & - \\
\hline Transport/ Storage & 5 & 14 & 100 & 86 & 86 & 21 & 57 & 36 & 36 & - & 7 & 29 & 29 & - \\
\hline Finance \& Insurance & 4 & 11 & 100 & 73 & 82 & 27 & 45 & 45 & 36 & - & - & 27 & 18 & - \\
\hline Community/ Health Services & 2 & 8 & 100 & 100 & 100 & 38 & 63 & 75 & 63 & 25 & 13 & 50 & 25 & - \\
\hline $\begin{array}{l}\text { Communication Property \& } \\
\text { Business Services }\end{array}$ & 3 & 6 & 100 & 100 & 100 & 50 & 100 & 33 & 33 & - & 17 & 33 & 17 & - \\
\hline Overall & $41(82 \%)$ & 139 & 100 & 81 & 79 & 25 & 59 & 51 & 50 & 15 & 15 & 32 & 17 & 6 \\
\hline
\end{tabular}

Table 3. Small Business Third Party Website Features by Third Party Type

\begin{tabular}{|c|c|c|c|c|c|c|c|c|c|c|c|c|c|c|}
\hline \multirow[b]{3}{*}{ Business Category } & \multirow{3}{*}{$\begin{array}{c}\text { Number of } \\
\text { businesses with } \\
\text { third party } \\
\text { services }\end{array}$} & \multirow{3}{*}{$\begin{array}{c}\text { Overall } \\
\text { number of } \\
\text { services } \\
\text { identified } \\
\end{array}$} & \multicolumn{12}{|c|}{ Website Features (\% use) } \\
\hline & & & \multicolumn{8}{|c|}{ Information Space } & \multicolumn{3}{|c|}{ Communication Space } & \multirow{2}{*}{$\begin{array}{c}\text { Transactions } \\
\text { Space } \\
\begin{array}{c}\text { Bookings and/or } \\
\text { payments }\end{array}\end{array}$} \\
\hline & & & Name & Address & Tel & Fax & Map & URL & $\begin{array}{c}\begin{array}{c}\text { About } \\
\text { the } \\
\text { business }\end{array} \\
\end{array}$ & Images & Email & $\begin{array}{l}\text { Email } \\
\text { form }\end{array}$ & $\begin{array}{c}\text { User } \\
\text { Reviews }\end{array}$ & \\
\hline Portal & 8 & 18 & 100 & 50 & 33 & 6 & 61 & 33 & 72 & 50 & 16 & 44 & 22 & 50 \\
\hline Directory & 40 & 121 & 100 & 86 & 86 & 28 & 59 & 53 & 47 & 10 & 15 & 30 & 17 & 0 \\
\hline Overall & & 139 & 100 & 81 & 79 & 25 & 59 & 51 & 50 & 15 & 15 & 32 & 17 & 6 \\
\hline
\end{tabular}

Table 4: Most frequently used Third Party Website Providers

\begin{tabular}{|c|c|c|c|c|c|c|c|c|c|c|c|}
\hline \multirow[b]{2}{*}{$\begin{array}{l}\text { Third Party Website } \\
\text { Provider }\end{array}$} & \multirow{2}{*}{$\begin{array}{l}\text { Number } \\
\text { of links }\end{array}$} & \multicolumn{10}{|c|}{ Business Category } \\
\hline & & $\begin{array}{l}\text { Accommodation, } \\
\text { Café, \& } \\
\text { Restaurant }\end{array}$ & Retail & $\begin{array}{l}\text { Personal } \\
\text { Services }\end{array}$ & Manufacturing & $\begin{array}{l}\text { Building/ } \\
\text { Construction }\end{array}$ & Wholesale & Transport/Storage & $\begin{array}{l}\text { Finance } \\
\& \\
\text { Insurance }\end{array}$ & $\begin{array}{l}\text { Community } \\
\text { Health } \\
\text { Services } \\
\end{array}$ & $\begin{array}{l}\text { Communication, } \\
\text { Property \& } \\
\text { Business Services }\end{array}$ \\
\hline Hotfrog & 22 & - & 4 & 1 & 3 & 1 & 2 & 3 & 3 & 2 & 3 \\
\hline True Local & 11 & - & - & 2 & 2 & 1 & - & 2 & 1 & 2 & 1 \\
\hline White Pages & 8 & 1 & - & - & 1 & - & 1 & 1 & 3 & - & 1 \\
\hline Yellow Pages & 7 & - & 1 & 2 & 1 & - & 1 & 2 & 1 & - & - \\
\hline AussieWeb & 6 & - & 1 & - & 1 & - & 2 & 1 & - & 1 & - \\
\hline LOCALBusinessguide & 5 & - & - & 4 & 1 & - & - & - & - & - & - \\
\hline Dlook & 4 & - & 1 & 1 & - & 1 & - & 1 & - & - & - \\
\hline Startlocal & 4 & - & - & - & 1 & - & - & 1 & 2 & - & - \\
\hline $\begin{array}{l}\text { Yahoo7 (using True } \\
\text { Local) }\end{array}$ & 4 & - & 1 & - & 1 & 1 & - & - & - & - & 1 \\
\hline
\end{tabular}

Copyright (C) 2011, Infonomics Society 
Whilst the author did expect to see some further evidence of online ordering and payments in other categories, the reader is reminded that this does not mean that these businesses do not engage in eecommerce transactions - it just appears to be that if they do it must be occurring through their own websites. This is perhaps explained by the results presented in Table 3, which shows the findings presented by the type of third party website being used by businesses - portal or directory.

Table 3 shows that 40 of the 41 businesses that had used third party services had used at least one directory service. Only eight of the businesses had used sites which could be classified as portals - those sites offering more services than just 'listings' of businesses. Differences in the overall instances of third party site uses were even starker - with only 18 examples of portal use found compared to 121 instances of directory services. An interesting finding is that the 18 instances of website use occurred in only three business categories - accommodation, café and restaurant (12 instances), retail (4) and personal services (2) - which are amongst the top listed categories in Table 2. Obviously, those services that offered booking and payment facilities were all classified as portal services and this explains the prominence of the accommodation, café and restaurant business category.

Table 3 also shows the differences in website features utilised in portal and directory services. There appeared to be less use of the 'simple' website features on portal websites, with address, telephone number and fax number details being more prominent on directory services. Perhaps this may be because customers are able to complete their interactions with the businesses on the portal, without having to refer back to the business as they would with a directory website? Supporting this notion, most of the remaining features (details about the business, pictures, email forms, user reviews and order/booking features) tended to be more prominent on portal websites.

There are also a number of different payment models that confront small businesses when they select third party websites. These have been classified as:

- Free websites: these sites either generate revenue through advertisements or are offered by industry groups or governments to support a particular group of small businesses (mostly industry or location based).

- Free plus pay websites: these sites offer a limited listing for free, but the business needs to pay a fee if it wishes to have an extended listing.

- Subscription websites: these websites require a fee to be paid upon listing.

- Commission websites: these websites charge a percentage fee per sale (or booking).
In all, there were 60 different third party providers that were identified in the study, meaning that on average each provider's services were used 2.32 times. Table 4 provides detail for the nine most frequently used third party providers, which comprised $51 \%$ of all of the third party links that were identified. Thus, $15 \%$ of the third party providers made up over half of the identified links.

An interesting finding from Table 4 is that the business category with the most third party links, the accommodation, café, \& restaurant sector, is the least represented sector in the list of most popular third party providers. The reason for this is that there are 17 providers that make up the 21 links in this category, with only three of the providers being used by more than one of the businesses in the study. Of these, Stayz (www.stayz.com.au) was the most popular, linked to by three of the five businesses in this sector. As its name suggests, Stayz is a specialist Australia-wide online accommodation booking service, with over 26,000 listings (as at January 2011). This sector is also characterized by the high number of industry-specific third party portals that are being used, which once again highlights its difference from other sectors in this study. This suggests that there is some consolidation yet to occur in relation to the number of third party providers operating in the sector.

Note that most of the third party providers listed in Table 4 are represented in a wide range of industry sectors, suggesting that most of them provide generalist services. The most popular third party providers will now be briefly examined.

The most frequently used third party provider was Hotfrog (www.hotfrog.com.au), who provide free business listings for Australian businesses. Hotfrog also provide similar services around the world (for instance, www.hotforg.com for the USA). Their claim on their website (January 2011) is that 2.5 million people are using Hotfrog to access businesses (there is no indication of whether this is in Australia or over all of the international Hotfrog websites). The information provided in a typical listing is the business name, full business contact details, the business website address, a description of the business and details of its products and/or services. A link to Google maps showing the location of the business is provided, as is the ability to generate 'directions' to the business.

The next most popular third party provider was True Local (www.truelocal.com.au), who describe themselves as a "directory of Australian businesses". They claim on their website (January 2011) that there are 8.6 million business searches made across the 'TrueLocal' network each month. The listing provides basic contact details with Google maps and directions, with the opportunity for web users to share the business details via FaceBook, Twitter and other sites. There is a also a feature where users can 
add a review for the business and rate its services from one to five 'stars'. There is also a 'quoting' service provided that seems similar to a tendering process, where someone can 'post' a project and businesses can submit a quote for the job. The website recommends that the decision to select a provider can then be made on the basis of the quoted price, the anticipated time of completion and the reviews placed by customers for the business on the TrueLocal website. Interestingly, the last listing in Table 4 is Yahoo7 - a business directory listing that uses the True Local database and has a very similar web interface to True Local.

The next two most popular third party providers are the White Pages (www.whitepages.com.au) and Yellow Pages (www.yellowpages.com.au) These services have evolved from traditional print directories into the online arena. They each offer basic business listings and a number of advanced services for a fee. These include a number of mobile and voice directory options in additional to just basic listings. Yellow Pages also provides a free basic listing (business name and contact details) for businesses that can be accessed through their printed directories and online sites (the latter can also be access via mobile telephones).

The final two third party providers to be discussed are AussieWeb (www.aussieweb.com.au) and LOCALBusinessguide

(www.localbusinessguide.com.au). AussieWeb provide a free business listing, comprising business name, contact details, the business website address, Google map and directions. To demonstrate their popularity for searches, their website displays a number of awards from HitWise Australia, the latest (as at January 2011) being as follows:

From January - June, 2009, www.aussieweb.com.au was ranked \#9 in the Hitwise Australia 'Business and Finance Business Directories' industry based on monthly average market share.

LOCALBusinessguide follows a slightly different business model in that it provides free listings (comprising business name, contact details and description), but also two extra options for an annual fee. Their Classic Listing (\$Aust99 per annum) offers more prominent listings, an image, business website listing, product listings, and other services. Their Power Listing (\$Aust299 per annum) also provides listings across more business categories, optimised search pages and prioritized and highlighted listings. The businesses in this study only took advantage of their free listing.

This discussion suggests that as many of the businesses in this study employ third party options at no financial cost to themselves that this factor is a driver for them to adopt. Table 5 shows the breakdown of third party websites by the payment model. The majority of the websites were free or 'free plus pay' sites. The typical options selected by businesses in this study on 'free plus pay' sites was to go with the 'free' option rather than the more expensive option with extra services. However, 30\% of the sites (42) did involve some type of payment, either through a subscription fee or a commission on bookings/ sales (refer Table 5). Note that half of the portal websites were commission based, and most of these were accommodation third party sites and allowed online bookings and payments to occur.

Table 5. Classification of Third Party Websites by Payment Model

\begin{tabular}{|l|c|c|c|}
\hline Payment model & $\begin{array}{c}\text { Portal } \\
\text { websites }\end{array}$ & $\begin{array}{c}\text { Directory } \\
\text { websites }\end{array}$ & Overall \\
\hline Free sites & 4 & 41 & 45 \\
\hline $\begin{array}{l}\text { Free plus pay } \\
\text { sites }\end{array}$ & 1 & 44 & 45 \\
\hline Subscription sites & 3 & 30 & 33 \\
\hline Commission sites & 9 & - & 9 \\
\hline Unknown & 1 & 6 & 7 \\
\hline Overall & $\mathbf{1 8}$ & $\mathbf{1 2 1}$ & $\mathbf{1 3 9}$ \\
\hline
\end{tabular}

Table 6 shows the breakdown of third party websites by their payment model and business sector. Note that three of the business sectors (Accommodation, Café, \& Restaurant; Personal Services and Wholesale) comprise almost two thirds of the paid options taken by businesses in the study. At the other end of the scale, the Building/ Construction; Community/Health Services and Communications, Property and Business Services sectors comprised only $5 \%$ of the paid options.

Table 6. Classification of Third Party Websites by Payment Model and Business Sector

\begin{tabular}{|l|c|c|c|}
\hline Business Sector & $\begin{array}{c}\text { Free or } \\
\text { free plus } \\
\text { pay }\end{array}$ & $\begin{array}{c}\text { Subscript } \\
\text { ion or } \\
\text { Commissi } \\
\text { on sites }\end{array}$ & $\begin{array}{c}\text { Unkno } \\
\text { wn }\end{array}$ \\
\hline $\begin{array}{l}\text { Accommodation, } \\
\text { Café, \& } \\
\text { Restaurant }\end{array}$ & 7 & 13 & 1 \\
\hline Retail & 11 & 3 & 2 \\
\hline Personal Services & 7 & 8 & 1 \\
\hline Manufacturing & 12 & 3 & 1 \\
\hline $\begin{array}{l}\text { Building/ } \\
\text { Construction }\end{array}$ & 16 & - & - \\
\hline Wholesale & 8 & 6 & 1 \\
\hline $\begin{array}{l}\text { Transport/ } \\
\text { Storage }\end{array}$ & 10 & 3 & 1 \\
\hline $\begin{array}{l}\text { Finance \& } \\
\text { Insurance }\end{array}$ & 7 & 4 & - \\
\hline $\begin{array}{l}\text { Community/ } \\
\text { Health Services }\end{array}$ & $\mathbf{9 0}$ & $\mathbf{4 2}$ & - \\
\hline $\begin{array}{l}\text { Communication } \\
\text { Property \& } \\
\text { Business Services }\end{array}$ & 5 & 1 & - \\
\hline Overall & 7 & & \\
\hline
\end{tabular}




\section{Implications and further research}

Little is known about the use of third party website providers by small business operators. This study has only examined a small number of Australian businesses (50), but has revealed some interesting insights into the usage of these sites. The first surprise to the author was the number of businesses in the study that actually employed third party websites. With $84 \%$ of small businesses in the study using their services then their existence, and the reliance on small businesses on their services, should be taken seriously by researchers.

The next interesting finding was the how separate the behaviour of the accommodation, café and restaurant sector compared to the other sectors. Although it requires further investigation, the information intensive nature of the tourism industry and its historical reliance on computerized solutions may in some way explain this occurrence. However, it appears that there is a large number of third party providers in this space.

The most popular third party providers covered many business sectors, but one of the key findings here is that most of the listings that were found would have occurred at no financial cost to the business. This is obviously a key outcome of the study. There were also a number of providers that offered free listings that did not seem to be as well patronized - so perhaps there is also a level of wordof-mouth or high rankings in search engines for these services that has helped them to become popular. This is worth further investigation.

It appeared that businesses in some sectors were more likely to adopt third party providers for some type of fee, but as the sample of the study is small this is something that could also be investigated in a later study.

\section{Conclusion}

It has been known for some time that small businesses have had access to third party websites, in the form of portals and directories, to extend their web presence. However, little has been known about the extent to which they use them and how the usage may differ across different types of small businesses. This paper has endeavoured to address this.

It appears from even this small sample of 50 small businesses that have used the services of 139 third party websites that there are differences that can be attributed to different business categories, with the accommodation, café and restaurant category leading the way in relation to the number of third party websites used and the types of website features that are used. Along the same lines, there was little use of third party websites in the community/health services and communication, property and business services categories.
The vast majority of third party websites used were simple directory services, with the more complex portal websites being used by the more prominent users of third party websites, namely the accommodation, café and restaurant; retail and personal services business categories.

However, there is evidence that there is less maturity in the third party websites of businesses in the accommodation, café and restaurant sector, with that sector not being represented in the more common third party providers used overall by the businesses in the sample.

Most businesses used directories that were free to use or were free for basic listings with a fee for extended listings. The more frequently used third party services in the study (Hotfrog, True Local, White and Yellow Pages, AussieWeb and LOCALBusinessguide had representation across a number of business sectors (except Accommodation, Café, \& Restaurant).

However, some $30 \%$ of the third party websites did involve some fee, either by subscription or through a commission on sales. These were employed predominantly by businesses in the Accommodation, Café, \& Restaurant; Personal Services and Wholesale sectors.

In all, the use of third party websites was far more conservative than the author expected, except in the accommodation, café and restaurant business sector. This may again reflect the conservative nature of small business owner/managers.

\section{References}

[1] S. Bingley, C. Sellitto and S. Burgess, "The importance of third party websites: A study of small accommodation providers in Australia," in 4th International Scientific Conference "Planning for the Future - Learning from the Past: Contemporary Developments in Tourism, Travel \& Hospitality”, 2009.

[2] S. Burgess, "Determining Website Content for Small Businesses: Assisting the Planning of Owner/Managers," International Journal of Knowledge Management Studies, vol. 2, pp. 143-161, 2008.

[3] S. Burgess, S. Bingley and C. Sellitto, "A Model for Website Content Decisions in Micro Businesses," Global Business \& Economics Anthology, vol. 1, pp. 474-487, 2007.

[4] S. Burgess, C. Sellitto and S. Karanasios, Effective Web Presence Solutions for Small Businesses: Strategies for Successful Implementation. Hershey, PA: Information Science Reference, 2009, pp. 326.

[5] S. Burgess, S., \& A. Tatnall, A, A business-revenue model for horizontal portals. Business Process Management Journal, vol. 13, no. 5, 2007, pp.662-676 
International Journal of Digital Society (IJDS), Volume 2, Issue 1, March 2011

[6] T. R. Eisenmann, R. Hallowell and M. Tripsas, Internet Business Models: Text and Cases. UK: McGraw-Hill Education-Europe, 2002.

[7] T. Jelassi and A. Enders, Strategies for E-Business: Creating Value through Electronic and Mobile Commerce: Concept and Cases. UK: Financial Times/Prentice Hall, 2005.

[8] M. Phillips, Successful E-Commerce: 10 Case Studies to show Small Business how to Profit from Online Commerce. Melbourne, Australia: Bookman, 1998.

[9] A. Tatnall, S. Burgess and M. Singh, "Small business and regional portals in Australia," in Encyclopaedia of ECommerce, E-Government and Mobile Commerce M. Khosrow-Pour, Ed. Hershey, PA: Idea Group Reference, 2006, pp. 1016-1021.

[10] Telstra Corporation, "Sensis E:Business report: The online experience of small and medium enterprises," Sensis, Australia, 2010. 